\title{
Clinical and laboratory profiles of urinary tract infection among children at Prof. Dr. R. D. Kandou Hospital Manado
}

\author{
Valentine Umboh \\ Adrian Umboh \\ Department of Pediatrics Faculty of Medicine Sam Ratulangi University \\ Prof. Dr. R.D. Kandou Hospital Manado \\ Email: umbohvalentine@yahoo.com
}

\begin{abstract}
Abstrak: Infeksi saluran kencing (ISK)masih sering ditemukan pada anak-anak dan berperan dalam tingginya jumlah pasien yang dirawat di rumah sakit. Oleh karena itudibutuhkan diagnosis dan penanganan dini terhadap pasien ISK. Penelitian ini bertujuan untuk menentukan profil klinik dan laboratorik ISK pada pasien yang dirawat di Bagian Anak RSUP Prof. Dr. R. D. Kandou Manado. Jenis penelitian ini ialah retrospektif menggunakan data pasien dari Desember 2009 sampai Desember 2014. Hasil penelitian mendapatkan 65 pasien terdiagnosis ISK berusia 0-15 tahun terdiri dari 37 berjenis kelamin perempuan dan 27 berjenis kelamin laki-laki. Data rekam medik mengenai gambaran klinis dan hasil laboratorium memperlihatkan persentae tertinggi ialah demam $(76,6 \%)$ diikuti mual dan muntah $(26,6 \%)$, nyeri perut(17,2\%), and diare (14,0\%). Pada hasil urinalisisdidapatkan $\mathrm{pH}$ urin $<6,5(62,5 \%)$ dan $\mathrm{pH}$ urin 6,5-8,0 (27,5\%). Kuman tersering dari hasil kultur urin ialah Proteus sp. (32,8\%), Staphylococcus aureus (20,\%), dan Escherichia coli (10,9\%). Simpulan: Gambaran klinik dan laboratorik dari anak-anak dengan infeksi saluran kencing di RSUP Prof. Dr. R. D. Kandou Manado tidak berbeda bermakna dengan di negara maju dan di negara berkembang lainnya. Walaupun demikian hasil penelitian ini dapat membantu pertimbangan diagnosis dini pada pasien anak.
\end{abstract}

Kata kunci: infeksi saluran kencing, kultur urin, demam, urinalisis

\begin{abstract}
Urinary tract infection (UTI) is still common among children all over the world and cause a significant number of patient admission to the hospital. Keeping in view the high incidence of UTI in children with associated morbidity and mortality, it is imperative to diagnose and to treat the infection as early as possible. This study aimed to determine the clinical and laboratory profiles of UTI among patients admitted at Pediatric Ward Prof. Dr. R. D. Kandou Hospital Manado. This was a retrospective study. Clinical and laboratory presentation of the UTI patients were obtained from the medical records from December 2009 to December 2014. The results showed that there were 65 cases of UTI aged 0 to 15 years in this study consisted of 37 females and 27 males. Fever was the commonest clinical presentation (76.6\%) followed by nausea and vomitting (26.6\%), flank pain (17.2\%), and diarrhea (14.0\%). From the urinalysis it was found that the urine pHs were $<6.5(62.5 \%)$ and 6.5-8.0 (27.5\%). Proteus sp. (32.8\%), Staphylococcus aureus (20.3\%), and Escherichia coli $(10.9 \%)$ were the most common bacteria found in urinary culture. Conclusion: Clinical and laboratory profile of urinary tract infection in children at Pediatric Ward Prof. Dr. R. D. Kandou Hospital Manado was not significantly different from that of other developing and developed countries. Albeit, it willhelp us in confirming early diagnosis of urinary tract infection among pediatrics patients.
\end{abstract}

Keywords: urinary tract infection, urine culture, fever, urinalysis 
A urinary trat infection (UTI) is a bacterial infection that affects any part of the urinary tract. It is one of the most common bacterial infections among children. However, the epidemiology of UTI is confounded due to variability and nonspecificity of signs and symptoms of infection in infants and young children. ${ }^{1}$ The incidence of UTI and its clinical impact are very different for both sexes and at different stages of life. ${ }^{2}$ It is known that UTI is more frequent in boys in thefirst 3 months of life, with sex distribution of 5:1 (male predominantion). By preschool age, the sex ratio is reversed, with majority of UTI occur in females. ${ }^{3}$ Although UTI is infrequently associated with mortality, it is still a significant cause of morbidity. Delayed treatment of UTI can lead to vesicoureteral reflux and renal scarring. Renal scarring has been cited asone of the most common causes of end stage renal disease in adults as well as in children. ${ }^{4}$

UTI is a common cause for a significant number of outpatient visits. ${ }^{3,5,6}$ Recurrence is common and occurs in approximately $18 \%$ of male infants and $26 \%$ of female infants. ${ }^{7}$ Fever remains a more common presentation in the neonates, infants, and younger children whereas older children present with other symptoms. ${ }^{8}$ About $80 \%$ of the infants with culture proved with UTI present with fever. ${ }^{9}$ Dysuria can also be the main symptom of the UTI in younger children and infants which presents as irritability during micturition. ${ }^{10}$ Dysuria may be associated with enuresis and foul smelling turbid urine. ${ }^{11}$ Along with other signs and symptoms failure to thrive, dysuria ise also noted in the children with recurrent UTI and may be the only positive physical finding. ${ }^{9}$ Urinalysis was also recommended in infants presenting with jaundice. ${ }^{12}$ Paediatric investigators have identified the risk factors associated with an increased risk of UTI in children less than 2 years of age. They include temperature higher than $39^{\circ} \mathrm{C}$, fever longer than two days, white race, age less than one year, and no other obvious source of fever.
The presence of two or more of the above risk factors yielded a sensitivity of $>99 \%$ and specificity of $71 \%$ for the detection of UTI in this age group. ${ }^{13,14}$

Urinary tract infection is defined as the presence of bacteria in urine along with symptoms of infection. The first and most critical step in establishing the diagnosis of UTI is the method by which the urine is collected. In young patients, care must be taken in preparing the perineum and periurethral area for placement of the sterile plastic receptacle, which will be used for collection of urine. In infants, the best way to obtain urine for culture aseptically is by urethral percutaneous suprapubic bladder aspiration or by catheterization. These procedures avoid the potential problem of contaminated urine cultures that often result from bag specimens. Older children and adolescents can be instructed to collect a midstream urine specimen after proper cleansing of the urethral area. Demonstration of bacteria microscopically is the most reliable and fastest mean to establish the diagnosis of UTI beforeresults of urine cultures are available. The presence of 105 colony forming units (CFU) of a single organism per $\mathrm{ml}$ of urine is diagnostic for UTI.

Studies conducted at Parkland Memorial Hospital in Dallas demonstrated that the incidence rate of UTI in infants (6 months of age and younger) was 1.65 cases/1000 live births from 1972 to 1975 , and 2.04 cases/1000 live births from 1977 to 1980 . The male:female ratios were $2.7: 1$ and 5:1, in the two time periods. ${ }^{10}$ Males are more susceptible to UTI before the age of 3 months; thereafter, the incidence is substantially higher in females. Estimation of the true incidence of UTI depends on the rates of diagnosis and investigation. At least $8 \%$ of girls and $2 \%$ of boys will suffer from UTI in childhood. ${ }^{7}$

In 2005, a study at Ayub Teaching Hospital in Pakistan aimed to obtain the clinical profile of UTI in children admitted at the pediatric wards. The result showed that the majority of UTI cases (46\%) belonged to the age group 13 to 60 months: 
The number of UTI cases was less among neonates; the number of cases increased in the older age groups but it declined in the 13-15 year age group. Fever was the most common presentation; $92 \%$ of the patients had history of fever. Dysuria was a common presentation in older children $(4 \%$ to $60.8 \%$ ). ${ }^{7}$ Also in 2005 , the profile of children with UTI who consulted at a Chilean pediatric emergency institution/ clinic showed that UTI was 1.78 times more frequent in girls. The most common clinical presentations were fever and urinary tract symptoms. For patients who were more than 2 years old, urinary tract symptoms and previous UTI were risk factors for UTI. The most frequent organism isolated was Escherichia coli $(86 \%){ }^{12}$ Based on the previous studies, reported incidence rates of childhood UTI vary. For boys, the reported incidence rates range from 0.17 to 18 per 1000 people per year. This variation may be explained by differences in setting, health care system, age range, case definition, or study period. The range of occurrence rates was found to be much smaller in studies carried out in general practice from 2000 to 2002. A national survey was conducted in Sweden involving general practice and patients 0 to 18 years old (published in 2006). The results showed an overall incidence rate of 19.0 episodes of UTI presented in general practice per 1000 people per year for children under age of 18 years $(95 \% \mathrm{CI}$ : 18.1 to 19.9). In other words, if 1000 children, who are 0 to 18 years old, and are monitored/checked for one year, their general practitioners would have made 19 times more diagnoses of UTI. The incidence rate in girls was almost 8 times higher than in boys (respectively, 34.4 episodes per 1000 person years vs 4.4 episodes per 1000 person years, $P<0.001) .{ }^{13}$

This study aimed to analyze and determine the incidence rate, as well as clinical and laboratory profiles of UTI among patients admitted at Prof. Dr. R. D. Kandou Hospital. with an idea to expedite the diagnosis and thus could reduce the morbidity associated with it.

\section{MATERIAL AND METHODS}

This was a retrospective and desciptive study. All patients admitted in the pediatric ward of Prof.Dr. R. D. Kandou Hospital Manado from December 2009 until December 2014 were included in the study. Non probability (convenience) sampling technique was applied. Charts of all eligible subjects were reviewed and the following infromation were collected: age, sex, signs and symptoms, urinalysisresults, and urine culture results. A detailed history was taken with special emphasis on the antecedent history of UTI and other diseases like diabetes mellitus, history of fever, dysuria, vomiting, urine colour, urinary stream, abdominal pain, and urethral discharge. All the patients were thoroughly examined especially looking for their height, weight, failure to thrive, temperature, jaundice, abdominal tenderness, palpable kidneys, palpable urinary bladder, as well as any other visible external deformity related to urinary tract and rachitic rosary.

\section{RESULTS}

There were 64 patients included in the study period from December 2009 to December 2014 consisted of 37 females $(57.8 \%)$ and 27 males (42.2\%). Fever was the most common clinical presentation $(76.6 \%)$ followed by nausea and vomitting $(26.6 \%)$, flank pain $(17.2 \%)$, and diarrhea $(14.0 \%)$. From the urinalysis it was found that patients with UTI had urine $\mathrm{pH}<6.5(62.5 \%)$ and $\mathrm{pH} 6.5-8.0(27.5 \%)$. Proteus sp. (32.8\%), S. aureus $(20.3 \%)$, and E. coli $(10.9 \%)$ were the most common bacteria found in urinary cultures (Fig. 1 and 2).

\section{DISCUSSION}

UTI is still a significant problem in Manado, Indonesia. The factors responsible for the high occurrence of UTI are the nonspecific clinical presentations in children, lack of appreciation of high morbidity and mortality associated with UTI, and the 


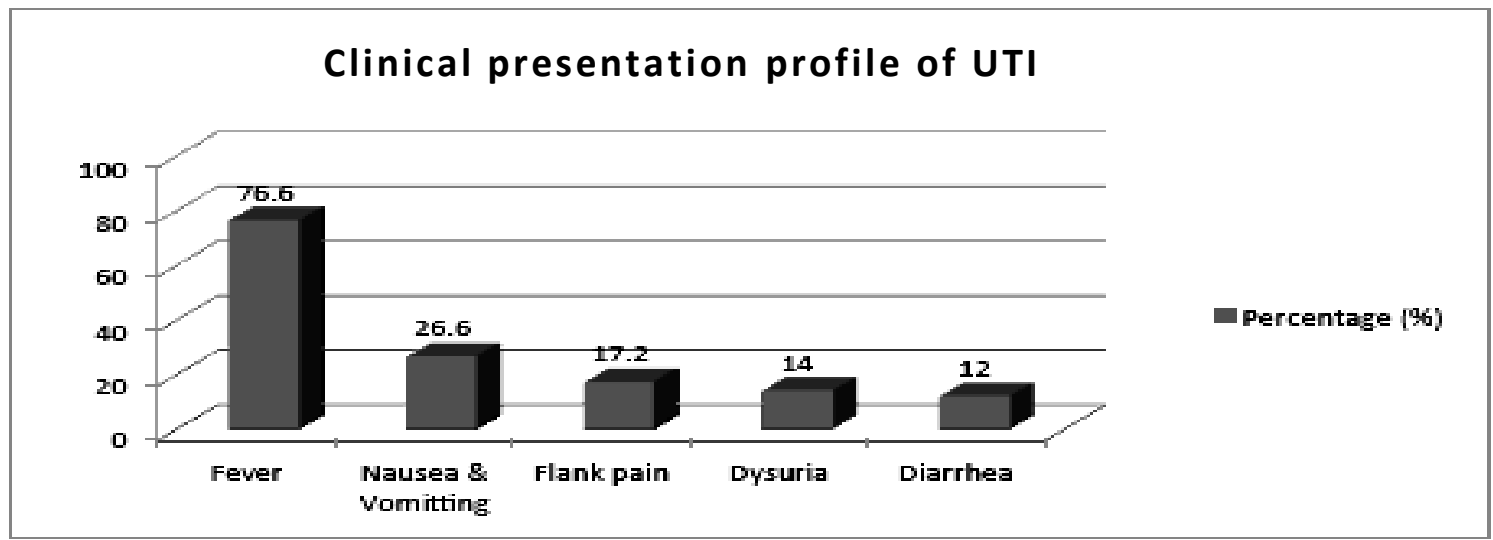

Figure-1. Clinical Presentation of Urinary Tract Infection

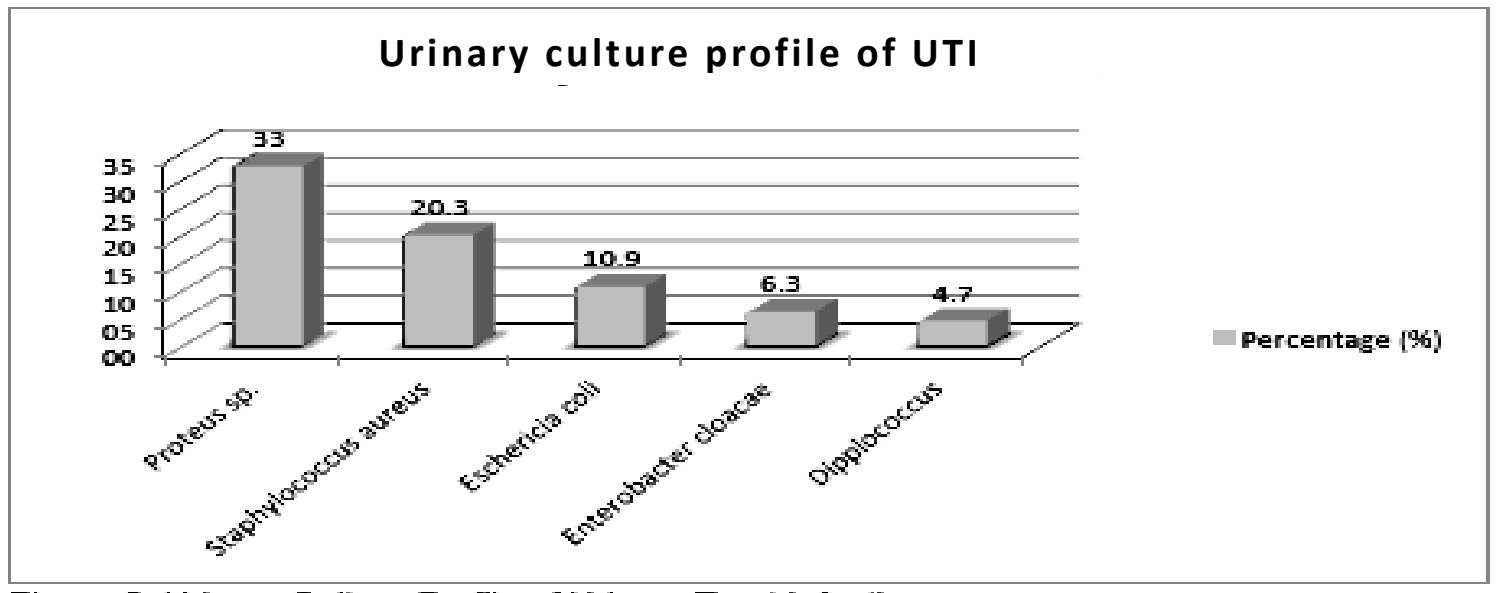

Figure-2. Urinary Culture Profile of Urinary Tract Infection

spectrum of microorganisms associated with it. ${ }^{15-17}$

Majority of patients (46\%) belonged to the 13 to 60 month age group and this coincides with other studies. ${ }^{15-17}$ Asreported by other studies, this could be due to the reason, that this age group of 13 to 60 months is more susceptible to infections due to their toilet training problems, and thus, more susceptible to infection. ${ }^{18}$ It is known that UTI is more frequent in boys in the first 3 months of life. It is also reported by many studies that the number of caseswas less in the neonatal period, however, it inclined with the increasing age and declined after the thirteen years of age till fifteen years. ${ }^{5,16}$ Overall, in terms of gender distribution, our study showed that UTI was 1.4 times more frequent in girls. This is very close to the value arrived at in the study conducted at a Chilean Hospital which showed that UTI was 1.78 times more frequent in girls. ${ }^{8}$

Similar to previous studies, fever was the most common symptom presentation for all age groups in the 64 enrolled cases; $76.6 \%$ of the patients had history of fever. The difference in the study was due to the fact that fever alone, as the only presenting symptom was considered by them. However other studies also indicated the high association between fever and urinary infection. $8,9,14,19-21$

Nausea and vomiting were common (26.6\%) in this study as compared to the studies from different countries. ${ }^{18,19}$ Flank pain is a common presentation in older children (4\% to $60.8 \%$ ), but it can also be a presenting symptom in the infants. ${ }^{19,22}$ Most of the observations were beyond 48 months of age. The difference seen in various studies might be due to the difference in the patients age groups. Flank pain was reported in $4 \%$ neonates, ${ }^{21}$ and up 
to $60.8 \%$ cases in patientsbeyond neonatal period. $^{15}$ There was a poor relationship between the urine colour and the urine culture of positive UTI. In our study, a significant number $(88 \%)$ of children presented with normal colour of urine and no change in the smell of the urine. Similar results were reported by a study conducted in St. Mary's Hospital, Portsmouth. ${ }^{11}$

A strong relationship was observed between UTI and combination of dysuria with weak urinary stream. In this study all the patients presenting with both dysuria and weak urinary stream had positive urine cultures. A significant percentage of children (28\%) presented with recurrent urinary infections. Among females, poor compliance and follow-up were identified as the major problems. In males, the urinary tract abnormalities were also a contributory. In this study, Proteus sp. $(32.8 \%)$ and Staphylococcus aureus $(20.8 \%)$ were the most common bacteria found in urinary cultures. Similar findings were also reported although Escherichia coli were the most common bacteria found followed by Proteus sp,Staphylococcus sp, and Pseudomonas sp. ${ }^{23}$

\section{CONCLUSION}

Clinical and laboratory profile of UTI among children in this study was not significantlydifferent from that of other developing and developed countries.

\section{REFERENCES}

1. Alinea MCD, Mantaring JBV III. A single blind, randomized controlled trial on the effect of cranberry juice as adjunct to antibiotics in the treatment of recurrent urinary tract infection in children. PIDSP J. 2002;6(3):45-52.

2. Jose PA. Acute urinary tract infection in childre. Proceedings of the 34th PPS Annual Convention and Golden Anniversary. Phil J Pediatr. 1997;Special Issue:29-31.

3. Qureshi AM. Clinical presentation of urinary tract infection among children at Ayub Teaching Hospital Abbottabad.
J Ayup Med Coll Abbottabad. 2005;17(2);79-81.

4. De Leon MAB. Prevalence of urinary tract infection in febrile infants and young children. Phil J Pediatr. 1997;46(3):185-7.

5. Langley JM, Hanakowski M, Leblanc JC. Unique epidemiology of nasocomial urinary tract infection in children. Am J Infect Control. 2001;29:94-8.

6. Falcao MC, Leone CR, D'Andrea RA, Berardi R, Ono NA, Vaz FA. Urinary tract infections in full-term newborn infants: value of urine culture by bag specimen collection. Rev Hosp Clin Fac Med Sao Paulo.1999;54:91-6.

7. Barnett BJ, Stephens DS. Urinary tract infection: an overview. Am J Med Sci. 1997;314:245-9.

8. Kaushal RK, Sumeet B, Sharma VK, Sood A, Goyal A. Urinary tract infection among children presenting with fever. Ind Pediatr. 2003;40:269-70.

9. Shaw KN, Shortliffe LMD. Urinary tract infection in the pediatric patient. Pediatr Clin North Am. 1999;46(6):1111-24.

10. Bagga A. Consensus statement on management of urinary tract infections. Ind Pediatr. 2001;38:1106-15.

11. Struthers S, Scanlon J, Parker $K$. Parental reporting of smelly urine and urinary tract infection. Arch Dis Child. 2003;88:250-2.

12. Garcia FJ, Negar AL. Jaundice as an early sign of urinary tract infection in infancy. Pediatrics. 2002;109:846-51.

13. Bartkowski DP. Recognizing UTIs in infants and children. Postgrad Med. 2001;109(1):171-81.

14. American Academy of Pediatrics. Practice parameter: the diagnosis, treatment and evaluation of the initial urinary tract infection in febrile infants and young children. Pediatrics. 1999;103:843-52.

15. Wammanda RD, Ewa BO. Urinary tract pathogens and their sensitivity pattern in children. Ann Trop Pediatr. 2002; 22:197-98.

16. Arslan S, Caksen H, Rastgeldi L. Use of urinary Gram stain for the detection of urinary tract infection in childhood. Yale J Biol Med. 2002;75:73-8.

17. Mehr SS, Powell CV, Curtis N. Cephalosporin resistant urinary tract 
124 Jurnal Biomedik (JBM), Volume 8, Nomor 2, Juli 2016, hlm. 119-124

infections in young children. J Paediatr Child Health. 2004;40(1-2):48-52.

18. Gallager SA, Hemphill RR. Urinary tract infections: Epidemiology, detection, and evaluation. [Cited 2003]. Available from: www.ahcpub.com.

19. Saleh SI, Tuhmaz MM, Sarkhouh MY. Urinary tract infection in children in Aljahra area, Kuwait: An overview. Kuw Med J. 2003;35(1):31-5.

20. Gorelick MH, Shaw KN. Screening test for UTI in children: A Meta analysis. Pediatrics. 1999;104(5):e54.
21. Pitetti RD, Choi S. Utility of blood cultures in febrile children with UTI. Am J Emerg Med. 2002;20(4):271-4.

22. Biyikli NK, Alpay H, Ozek E, Akman I, Bilgen $H$. Neonatal urinary tract infections: Analysis of the patients and recurrences. Pedtr Int. 2004;46:21-5.

23. Bouallegue O, Saidani M, Ben Mohammed S. Bacteriologic features of urinary tract infections in children in the Sousse Area, Tunisia. Tunis Med. 2004;82(8):742-6. 